\title{
PENGARUH DOSIS PUPUK MIKORIZA VESICULAR ARBUSKULAR TERHADAP SIFAT KIMIA TANAH PADA TANAMAN KEDELAI (Glycine max (L) Merr).
}

\author{
Julianus Jeksen \\ Julianus_jeksen@yahoo.com
}

Program Studi Agroekoteknologi, Fakultas Pertanian Universitas Flores, Ende

\begin{abstract}
ABSTRAK
This study aims at determining the influence of vesicular arbuscular mycorrhiza dosage on soil chemical properties of soybean and its optimum dosage that can increase the soil available-P on crops of soybean. This research was conducted in Lokoboko village, Ndona Subdistrict of Ende regency. This study used Randomized Block Design and a singlepattern factor consists of five treatments and four replications namely $\mathrm{M}_{0}: 0$ gr pot $^{-1}$ or without mycorrhiza, $\mathrm{M}_{5}: 5 \mathrm{gr}$ pot $^{-1}$ mycorrhiza, $\mathrm{M}_{10}: 10 \mathrm{gr}_{\text {pot }^{-1}}$ mycorrhiza, $\mathrm{M}_{15}: 15 \mathrm{gr}_{\text {pot }}$ ${ }^{1}$ mycorrhiza and $\mathrm{M}_{20}$ : $20 \mathrm{gr}$ pot $^{-1}$ mycorrhiza. The variables of this study are plantabsoption $\mathrm{P}\left(\mathrm{mg} \mathrm{tan}^{-1}\right)$, soil-available $\mathrm{P}\left(\mathrm{mg} \mathrm{kg}^{-1}\right)$, soil-organic $\mathrm{C}(\%)$ and $\mathrm{pH}$ of soil. The results showed that the use of vesicular arbuscular mycorrhiza fertilizer for crops of soybean could increase soil-available $\mathrm{P}$ in $56,26 \%$, plant-absoption $\mathrm{P}$ in $65 \%, \mathrm{pH}$ of soil in $6,06 \%$ and soil-organic $\mathrm{C}$ in $62,68 \%$.The use of vesicular arbuscular mycorrhiza fertilizer on the dosage of $20 \mathrm{~g}$ has the better effectivity in increasing soil-available $\mathrm{P}$ in soybean plant.
\end{abstract}

Key words: Mycorrhiza, soybean, soil-available P

PENDAHULUAN

Kedelai (Glycine max. (L.)Merr.) merupakan salah satu komoditas utama kacang-kacangan yang menjadi andalan nasional, karena merupakan sumber protein nabati penting untuk diversifikasi pangan dalam mendukung ketahanan pangan nasional (Hasanuddin et al, 2005 dalam Atman, 2006). Kebutuhan kedelai Indonesia rata-rata sekitar 2,2 juta ton/tahun dimana produksi dalam negeri hanya mampu mencukupi 35-40\% sedangkan 60-65\% dipenuhi dari impor. Salah satu masalah dalam peningkatan produksi kedelai adalah belum optimalnya petani melakukan budidaya kedelai serta menurunnya kualitas sifat fisik, kimia dan biologi tanah (Marwoto dan Suharsono, 2008).

Kedelai (Glycine max Merr) varietas "Wilis" dilepas tahun 1983, oleh Balai Penelitian Tanaman Pangan 
Julianus: Pengaruh dosis pupuk mikoriza vesikular arbuskular terhadap sifat kimia tanah pada tanaman kedelai (Glycine max (L) Merr).

Bogor. Wilis berasal dari galur F4 persilangan varietas No. 1682 dengan Orba, yang disilangkan di Bogor pada tahun 1975. Keturunan dari persilangan diseleksi dengan metode seleksi massa berstrata berdasarkan umur matang, mulai generasi F2 Saimpai F4. Pembuatan galur murni dilakukan pada generasi F4. Galur yang terbaik adalah No. 1682/1343-1-1-0, yang kemudian dilepas sebagai varietas baru, dengan nama Wilis.

Berdasarkan hasil penelitian Sunarmo, dkk Dari rata-rata 18 lingkungan percobaan antara kedelai varietas willis dan kedelai varietas unggul lama, Wilis menghasilkan tertinggi, sebesar $1626 \mathrm{~kg} / \mathrm{ha}$, dengan kisaran antara 1024-2744 kg/ha. Dibandingkan varietas unggu1 lama Orba, wilis menghasilkan $309 \mathrm{~kg} / \mathrm{ha}$, atau 24 persen 1ebih tinggi. Hasil rata-rata Orba 131 kg/ha.

Tanaman kedelai dapat tumbuh baik jika dreanase dan aerase tanah baik, untuk dapat tumbuh subur kedelai menghendaki tanah yang subur, gembur, serta kaya akan bahan organik. Pada akar terdapat bintil-bintil akar yang berkoloni dari bakteri Rhizhobium japonicum yang terbentuk di akar, yang dapat mengikat $\mathrm{N}$, bersimbiosa dengan tanaman. Tanah yang dapat ditanami kedelai memiliki air dan hara tanaman untuk pertumbuhannya cukup. Serapan unsur $\mathrm{P}$ oleh tanaman juga dipengaruhi oleh adanya unsur $\mathrm{N}$. Pemberian unsur $\mathrm{P}$ yang dikombinasikan dengan $\mathrm{N}$ dapat meningkatkan serapan $\mathrm{P}$ oleh tanaman. Tanaman kedelai memerlukan unsur $\mathrm{P}$ dalam setiap masa pertumbuhannya. Posfat didalam tanah mudah tersedia pada $\mathrm{pH}$ tanah antara 5,5 - 7,0 jika pH tanah berada diatas atau dibawah kisaran tersebut maka serapan $\mathrm{P}$ oleh tanaman akan menyusut. (kesuburankelasb.blogspot.com)

Kabupaten Ende memiliki luas wilayah sebesar 204.660 ha, dari total tersebut lahan yang dapat di budidayakan untuk pertanian seluas 55.932 ha $(27,32$ $\%$ dengan perincian $24,05 \%$ berupa lahan kering dan 3,27\% berupa lahan basa. Produksi kedelai di Kabupaten Ende pada tahun 2007 sebanyak 13 ton dengan luas panen 23 ha atau rata-rata $565 \mathrm{~kg} / \mathrm{ha}$ (Distan Kab.Ende,2007). Salah satu permasalahan budidaya kedelai di lahan kering yaitu sifat-sifat tanah yang masam sebagai ketersediaan fosfat $(\mathrm{P})$ menjadi kendala utama. 
Julianus: Pengaruh dosis pupuk mikoriza vesikular arbuskular terhadap sifat kimia tanah pada tanaman kedelai (Glycine max (L) Merr).

Selain ditentukan oleh faktor tanah, kebutuhan pupuk $P$ tanaman juga tergantung faktor tanaman. Berdasarkan responnya terhadap pemberian $\mathrm{P}$, tanaman ada yang toleran dan ada pula yang sensitif. Tanaman toleran $\mathrm{P}$ adalah tanaman yang masih dapat tumbuh dengan baik walaupun kadar $\mathrm{P}$ tanah rendah. Termasuk dalam kelompok ini adalah: singkong, kacang tanah, dan lainlain. Sebaliknya tanaman sensitif $\mathrm{P}$ adalah tanaman yang pertumbuhannya akan terganggu apabila kadar $\mathrm{P}$ tanah rendah, misalnya: kedelai, tomat, selada, dan lainlain (Havlin et al., 1999). Tanaman toleran $\mathrm{P}$ memerlukan pupuk $\mathrm{P}$ dalam jumlah yang sedikit untuk mencapai hasil optimum sedangkan tanaman sensitif $\mathrm{P}$ memerlukan jumlah yang lebih banyak (Nursyamsi et al., 2003).

Menurut Anonimus mengatakan bahwa pada lahan kering masam, masalah ketersediaan fosfat $(\mathrm{P})$ menjadi kendala utama dalam meningkatkan hasil dan hanya 10-30 \% dari pemupukan P dapat dimanfaatkan oleh tanaman. Hal ini terjadi karena adanya proses pengikatan atau fiksasi $\mathrm{P}$ yang cukup tinggi oleh tanah oleh pupuk yang diberikan. Pada kondisi tanah masam, unsur fosfat akan terjerap oleh $\mathrm{Al}$ dan besi, sedangkan pada kondisi tanah basa unsur fosfat akan terjerap oleh $\mathrm{Cad}$ an $\mathrm{Mg}$, Salah satu upaya penentuan kebutuhan fosfat yaitu dengan pemanfaatan pupuk hayati.

Salah satu mikroorganisme yang cukup penting dalam memanfaatkan fosfat yang ada di dalam tanah adalah Jamur Mikoriza yang berpotensi memfasilitasi penyediaan berbagai unsur hara bagi tanaman terutama unsur $\mathrm{P}$, karena Mikoriza mempunyai enzim phosphatase yang dapat membantu penyerapan $\mathrm{P}$ dari tidak tersedia menjadi tersedia bagi tanaman.

Hasil inokulasi ini dapat meningkatkan hara fosfat secara langsung, atau memindahkan fosfat lansung pada tanaman atau lebih sederhana sebagai ketersediaan fosfat di dalam tanah lebih besar. Menurut Imas dkk (1989) beberapa manfaat yang dapat diperoleh oleh tanaman inang dari adanya asosiasi mikoriza adalah dapat meningkatkan penyerapan unsur hara, meningkatkan ketahanan terhadap kekeringan, tahan terhadap patogen akar serta memproduksi hormon dan zat pengatur tumbuh. Hasil penelitian (Siswin, dkk), menunjukkan bahwa 
Julianus: Pengaruh dosis pupuk mikoriza vesikular arbuskular terhadap sifat kimia tanah pada tanaman kedelai (Glycine max (L) Merr).

pemberian kascing dan inokulasi MVA memberikan kontribusi yang nyata terhadap serapan hara $\mathrm{N}$ dan $\mathrm{P}$ tanaman jagung. Serapan tertinggi di peroleh pada kombinasi perlakuan $100 \mathrm{~g} \mathrm{pot}^{-1}$ kascing dan $10 \mathrm{~g}$ pot $^{-1}$ inokulasi MVA. Dibandingkan dengan kontrol, kontribusi pemberian kascing dan MVA pada perlakuan tersebut mampu meningkatkan serapan $\mathrm{N}$ sebesar $112,2 \%$ dan serapan $\mathrm{P}$ sebesar $60,9 \%$. Karena hal-hal tersebut di atas, maka peneliti melakukan penelitian ini dengan tujuan untuk mengetahui pengaruh dosis Mikoriza Vesicular Arbuskular terhadap sifat kimia tanah pada tanaman kedelai dan dosis optimumnya yang dapat meningkatkan Ptersedia tanah pada tanaman kedelai.

\section{METODE PENELITIAN}

Percobaan ini merupakan percobaan Pot di dalam Rumah Kaca Fakultas Pertanian Universitas Flores, Desa Lokoboko, Kecamatan Ndona, Kabupaten Ende. Kondisi tanah di kebun percobaan memiliki pH tanah 6,1, DHL tanah 1,54 C- Organik tergolong rendah dengan nilai $1,25 \%, \mathrm{~N}$-total tergolong rendah dengan nilai $0,17 \%, \mathrm{P}$ - tersedia tergolong sedang dengan nilai $13,94 \% \mathrm{mg}$, $\mathrm{K}$ - tersedia $78,20 \mathrm{ppm}$ dan memiliki tekstur tanah lempung berdebu. Waktu Percobaan dimulai sejak bulan Agustus sampai dengan bulan Oktober.

\section{Bahan dan Alat}

Bahan-bahan yang digunakan dalam percobaan ini adalah benih kacang kedelai Varietas Willis, Mikoriza Versikular Abuskular dan pupuk kandang ayam. Alat-alat yang digunakan adalah pacul, sabit, ajir, ember plastik, sekop, timbangan, oven, meteran, penggaris, tali rafia, kantong plastik, alat tulis, dan kamera.

\section{Rancangan Percobaan}

Rancangan yang digunakan dalam percobaan ini adalah Rancangan Acak Kelompok (RAK) dengan pola faktor tunggal yang terdiri dari lima perlakuan yaitu: $\mathrm{M}_{0:} 0 \mathrm{gr}_{\text {pot }}{ }^{-1}$ atau tanpa mikoriza, $\mathrm{M}_{5}: 5 \mathrm{gr} \mathrm{pot}^{-1}$ mikoriza, $\mathrm{M}_{10}: 10 \mathrm{gr} \mathrm{pot}^{-}$ ${ }^{1}$ mikoriza, $\mathrm{M}_{15}: 15 \mathrm{gr}_{\text {pot }^{-1}}$ mikoriza dan $\mathrm{M}_{20}$ : 20 gr pot $^{-1}$ mikoriza.

\section{Pengambilan Sampel Tanah}

Pengambilan sampel tanah dilakukan di kawasan kebun percobaan Fakultas Pertanian Universitas Flores, Desa Lokoboko, Kecamatan Ndona, Kabupaten Ende. Tanah di ambil pada 5 titik yang berbeda di sekitar kawasan tersebut, masing masing titik diambil sebanyak 1 
Julianus: Pengaruh dosis pupuk mikoriza vesikular arbuskular terhadap sifat kimia tanah pada tanaman kedelai (Glycine max (L) Merr).

$\mathrm{kg}$, tanah yang telah diambil dicampur menjadi satu kemudian dikering udarakan dan diayak halus sehingga siap dianalisis di laboratorium.

\section{Persiapan media tanam}

Media tanam yang digunakan adalah tanah yang berasal dari kebun percobaan Fakultas Pertanian Universitas Flores. Tanah dikeringkan dan dibersihkan dari sisa-sisa tanaman dan kotoran, dihaluskan dan diayak kemudian dimasukan ke dalam polibag.

\section{Persiapan benih dan penanaman}

Benih yang digunakan adalah benih kedelai hibrida varietas willis. Biji kedelai dipilih berdasarkan bentuk dan ukurannya untuk mendapatkan benih yang seragam. Benih yang akan ditanam terlebih dahulu direndam dalam air selama \pm 30 menit kemudian ditiriskan dan ditanam. Benih ditanam dalam pot sedalam 1-2 cm dari permukaan tanah dan setiap pot terdapat 3 benih. Pot diletakan sesuai dengan denah per yang telah diacak. Satu minggu tumbuh dilakukan penjarangan dengan menyisakan dua tanaman per pot.

\section{Perlakuan mikoriza}

Pupuk mikoriza diberikan pada saat tanam yaitu dengan dosis $\mathrm{M}_{0}: 0 \mathrm{gr}_{\text {pot }}{ }^{-1}$ atau tanpa mikoriza, $\mathrm{M}_{5}$ : $5 \mathrm{gr} \operatorname{pot}^{-1}$ mikoriza, $\mathrm{M}_{10}: 10$ gr pot $^{-1}$ mikoriza, $\mathrm{M}_{15}$ : $15 \mathrm{gr}$ pot $^{-1}$ mikoriza, $\mathrm{M}_{20}$ : $20 \mathrm{gr}_{\text {pot }^{-}}$ ${ }^{1}$ mikoriza. Sebelum pupuk mikoriza diberikan terlebih dahulu membuat lubang pada media tanam dengan kedalaman $\pm 10 \mathrm{~cm}$ kemudian pupuk mikoriza dimasukan ke dalam lubang tersebut sesuai dengan dosis yang telah ditentukan selanjutnya ditimbun dengan tanah, kemudian benih kedelai dimasukkan ke dalam lubang tanam.

\section{Pemupukan}

Untuk menambah unsur hara dalam tanah maka diberikan pupuk kandang ayam sebanyak 20 ton/ha atau sebanyak 1 kg/pot. Pemberian pupuk kandang ayam dilakukan bersamaan dengan pengisian tanah ke dalam polibag.

\section{Pemeliharaan Tanaman}

Pemeliharaan tanaman meliputi penyulaman, penjarangan, penyiangan, pembumbun serta pengendalian hama dan penyakit. Penyulaman di lakukan pada biji yang tidak tumbuh normal tujuh hari setelah tanam. Penyulaman dilakukan dengan menggunaan bibit kedelai yang telah di tanam bersamaan pada polybag. Setelah tanaman tumbuh perlu di lakukan penjarangan dengan menyisakan 2 
Julianus: Pengaruh dosis pupuk mikoriza vesikular arbuskular terhadap sifat kimia tanah pada tanaman kedelai (Glycine max (L) Merr).

tanaman per lubang sehingga pertumbuhannya baik dan merata. Penjarangan di lakukan 2 minggu setelah tanam, dengan tujuan agar populasi tanaman dalam pot tetap dan sama. Penyiangan dan pembumbunan dilakukan bersamaan setelah tanaman berumur 2 minggu dengan tujuan untuk menghilangkan gulma yang tumbuh di sekitar tanaman dan membuat tanah gembur. Pengendalian hama dan penyakit dilakukan apabila terdapat gejala serangan pada tanaman tersebut.

\section{Panen}

Panen kedelai di lakukan apabila sebagian besar tanaman sudah berbunga ditandai dengan munculnya bunga pada seluruh tanaman kedelai atau \pm pada umur 45 hst.

\section{Variabel Pengamatan}

1. Serapan $\mathrm{P}$ tanaman $\left(\mathrm{mg} \tan ^{-1}\right)$

Pengamatan kadar P jaringan tanaman

dilakukan pada saat tanaman berumur 45 hst selanjutnya tanaman tersebut dianalisis di laboratorium

2. $\quad \mathrm{P}$ tersedia tanah $\left(\mathrm{mg} \mathrm{kg}^{-1}\right)$

$\mathrm{P}$ tersedia tanah diamati dengan mengambil sampel tanah sebanyak 500 g pada masing - masing perlakuan kemudian dikering udarakan dan diayak halus sehingga siap dianalisis di laboratorium. Pengamatan diakukan pada akhir percobaan

3. C-organik tanah (\%)

C-organik tanah diamati dengan mengambil sampel tanah sebanyak 500 g pada masing - masing perlakuan kemudian dikering udarakan dan diayak halus sehingga siap dianalisis di laboratorium. Pengamatan diakukan pada akhir percobaan

4. $\mathrm{pH}$ tanah

$\mathrm{pH}$ tanah diamati dengan mengambil sampel tanah sebanyak 500 g pada masing-masing perlakuan kemudian dikering udarakan dan diayak halus sehingga siap dianalisis di laboratorium. Pengamatan dilakukan pada akhir percobaan

\section{Analisis Data}

Data hasil pengamatan yang diperoleh merupakan data hasil analisis laboratorium dari setiap sampel tanah yang dikumpulkan secara komposit.

\section{HASIL DAN PEMBAHASAN}

\section{P-tersedia tanah}

Berdasarkan hasil analisis laboratorium kandungan P-tersedia tanah mengalami peningkatan mulai dari kontrol sampai dengan perlakuan M20. 
Julianus: Pengaruh dosis pupuk mikoriza vesikular arbuskular terhadap sifat kimia tanah pada tanaman kedelai (Glycine max (L) Merr).

Kandungan P-tersedia yang tertinggi yaitu 28,58 ppm diperoleh pada perlakuan mikoriza $20 \mathrm{~g}$ (M20) atau lebih tinggi sebesar 56,26\% dari kandungan Ptersedia pada perlakuan tanpa mikoriza (M0).

Percobaan ini menunjukkan bahwa setiap peningkatan dosis pupuk mikoriza vesicular arbuskular kandungan $P$ tersedia tanah mengalami peningkatan yang yang sangat siginifikan, hal ini terbukti dengan peningkatan $\mathrm{P}$ tersedia tanah dari perlakuan M0 sampai pada perlakuanM20.

Peningkatan P-tersedia tanah erat kaitannya dengan penambahan mikoriza dengan sebagai pupuk hayati. Mikoriza mempunyai enzim phosphatase yang dapat membantu penyerapan $\mathrm{P}$ dari tidak tersedia menjadi tersedia bagi tanaman. Mekanismenya adalah asam fosfatase yang terdapat pada hifa aktif tumbuh serta peningkatan aktivitas enzim phosphatase pada permukaan akar akibatnya menyebabkan fosfat anorganik dibebaskan dari fosfat organik pada daerah dekat permukaan sel akar sehingga memudahkan fosfat dapat diserap (Kartini, 1997).
Hal sangat penting, yaitu Mikoriza juga diketahui berinteraksi sinergis dengan bakteri pelarut fosfat atau bakteri pengikat N. Inokulasi bakteri pelarut fosfat (PSB) dan mikoriza danat meningkatkan serapan $\mathrm{P}$ oleh tal tomat (Kim et al,1998) dan pada tal gandum (Singh dan Kapoor, 1999). Adanya interaksi sinergis antara VAM dan bakteri penambat N2 dilaporkan oleh Azcon dan Al-Atrash (1997) bahwa pembentukan bintil akar meningkat bila tanaman alfalfa diinokulasi dengan Glomus moseae. Sebaliknya kolonisasi oleh jamur mikoriza meningkat bila tanaman kedelai juga diinokulasi dengan bakteri penambat N, B. japonicum.cendawan mikoriza ini memiliki enzim pospatase yang mampu menghidrolisis senyawa phytat (myinosital 1,2,3,4,5,6 hexakisphospat). Phytat adalah senyawa phospat komplek, phytat tertimbun didalam tanah hingga $20 \%-50 \%$ dari total phospat organik, merupakan pengikat kuat (chelator) bagi kation seperti Kalsium (Ca++), Magnesium (Mg++), Seng ( $\mathrm{Zn++}$, Besi $(\mathrm{Fe}++)$, dan protein.

\section{Serapan P Tanaman}


Julianus: Pengaruh dosis pupuk mikoriza vesikular arbuskular terhadap sifat kimia tanah pada tanaman kedelai (Glycine max (L) Merr).

Berdasarkan hasil analisis laboratorium kadar P tanaman mengalami peningkatan mulai dari kontrol sampai dengan perlakuan M20. Kandungan Ptersedia yang tertinggi yaitu 0,4 diperoleh pada perlakuan mikoriza $20 \mathrm{~g}$ (M20) atau lebih tinggi sebesar $65 \%$ dari kandungan kadar $\mathrm{P}$ tanaman pada perlakuan tanpa mikoriza (M0).

Percobaan ini menunjukkan bahwa setiap peningkatan dosis pupuk mikoriza vesicular arbuskular kandungan Ptanaman mengalami peningkatan yang yang sangat siginifikan, hal ini terbukti dengan peningkatan serapan Ptanaman dari perlakuan M0 sampai pada perlakuan M20.

Santoso (1994) mengatakan bahwa mikoriza merupakan organisme yang tumbuh secara sismbiosis mutualistis dengan tanaman inangnya. Menurut Handayanto (2007) hifa jamur mikoriza sangat berpotensi untuk meningkatkan luas permukaan serapan akar sampai dengan $80 \%$, sehingga cendawan mikoriza dapat meningkatkan penyerapan berbagai unsur hara sehingga status nutrisi tanaman dapat diperbaiki, terbukti dengan meningkatnya serapan $\mathrm{P}$ tanaman.
Seperti diketahui bahwa inokulasi mikoriza dapat meningkatkan serapan $\mathrm{P}$ oleh tanaman, karena mikoriza dengan hifa eksternal, selain dapat memperluas jangkauan rambut akar yang berarti memperluas daerah penyerapan, juga dapat menembus daerah penipisan nutrien (zone of nutrient depletion) yang terdapat di sekitar perakaran dan menyerap unsur hara dari daerah tersebut. Akar yang tidak terinfeksi mikoriza tidak dapat menjangkaunya walaupun dengan rambut-rambut akar yang banyak. Hal ini karena diameter hifa mikoriza yang relatif kecil (rata-rata berukuran 2-5 $\mu \mathrm{m}$ ) sehingga mudah menerobos pori-pori tanah yang tidak dapat ditembus oleh rambut-rambut akar (Bethlenfalvay and Linderman, 1992). Mikoriza juga menghasilkan enzim fosfatase yang mampu mengkatalis hidrolisis komplek fosfat tidak larut yang terdapat di dalam tanah menjadi bentuk fosfat larut yang tersedia bagi tanaman (Fakuara dan Setiadi, 1990 dalam Niswati, et al., 1996). Selanjutnya fosfat larut ini dengan cepat akan diserap langsung oleh hifa eksternal mikoriza dan kemudian ditransfer ke tanaman inang. Dengan demikian tanaman yang diinokulasi mikoriza 
Julianus: Pengaruh dosis pupuk mikoriza vesikular arbuskular terhadap sifat kimia tanah pada tanaman kedelai (Glycine max (L) Merr).

mempunyai kemampuan untuk menyerap fosfat yang terikat dalam tanah dan fosfat dari pupuk (Manske, 1998 dalam Sastrahidayat, et al., 1999), sehingga penyerapan $\mathrm{P}$ menjadi lebih besar dibanding tanaman yang tidak diinokulasi mikoriza.

Fenomena peningkatan serapan $\mathrm{P}$ pada tanaman cabai merah yang diinokulasi mikoriza juga dilaporkan oleh Rahayu dan Santosa (1995), serta Gaur et al., (1998). Selanjutnya Soemartiningsih, et al., (1999) dan Liu, et al., (2000) melaporkan bahwa kadar unsur P jaringan tanaman yang diinokulasi mikoriza lebih tinggi dibanding tanaman non mikoriza. Demikian juga hasil penelitian Sastrahidayat et al., (1999) bahwa kandungan unsur $\mathrm{P}$ tanaman kapas (Gossypium hirsutum L.) lebih tinggi pada perlakuan inokulasi mikoriza dibanding tanpa inokulasi, dengan efisiensi serapan P $20-23 \%$.

pH Tanah dan C-organik Tanah (\%)

$$
\begin{aligned}
& \text { Berdasarkan hasil analisis } \\
& \text { laboratorium kadar } \mathrm{pH} \text { tanah dan C- } \\
& \text { organik mengalami peningkatan mulai } \\
& \text { dari kontrol sampai dengan perlakuan } \\
& \text { M20. Kandungan pH tanah yang tertinggi } \\
& \text { yaitu 6,6 diperoleh pada perlakuan }
\end{aligned}
$$

mikoriza $20 \mathrm{~g}$ (M20) atau lebih tinggi sebesar 6,06\% dari kandungan $\mathrm{pH}$ tanah pada perlakuan mikoriza 5 dan $10 \mathrm{~g}$ (M5 dan M10) (Tabel 4.3). Kandungan Corganik yang tertinggi 3,35 diperoleh pada perlakuan mikoriza $20 \mathrm{~g}$ (M20) atau lebih tinggi sebesar 62,68\% dari kandungan C-organik pada perlakuan tanpa mikoriza (M0).

Percobaan ini menunjukkan bahwa setiap peningkatan dosis pupuk mikoriza vesicular arbuskular kandungan $\mathrm{pH}$ tanah dan C-Organik Tanah mengalami peningkatan yang yang sangat siginifikan, hal ini terbukti dengan peningkatan $\mathrm{pH}$ tanah dan C-Organik Tanah dari perlakuan M0 sampai pada perlakuan M20.

Cendawan pada umumnya lebih tahan terhadap perubahan $\mathrm{pH}$ tanah. Meskipun demikian daya adaptasi masing-masing spesies cendawan MVA terhadap $\mathrm{pH}$ tanah berbeda-beda, karena $\mathrm{pH}$ tanah dapat mempengaruhi perkecambahan, perkembangan dan peran mikoriza terhadap pertumbuhan tanaman. Menurut Mosse, (1981) dalam Atmaja, (2001), mengatakan bahwa Glomus fasciculatus berkembang kurang baik pada kondisi pH masam. Sedangkan 
Julianus: Pengaruh dosis pupuk mikoriza vesikular arbuskular terhadap sifat kimia tanah pada tanaman kedelai (Glycine max (L) Merr).

Glomus fasciculatus berkembang dengan baik pada kondisi pH netral.

Perubahan $\mathrm{pH}$ tanah mempunyai konsekuensi langsung terhadap Corganik. Hal ini disebabkan karena peningkatan $\mathrm{pH}$ tanah sampai mendekati netral akan menyebabkan perombakan bahan organik semakin cepat sehingga akhirnya nilai $\mathrm{C}$ organik tanah dapat meningkat.

\section{Kesimpulan}

Berdasarkan hasil penelitian dapat disimpulkan sebagai berikut :

1. Pemberian Mikoriza Vesicular Arbuskular pada tanaman kedelaimampu meningkatkan kandungan $\mathrm{P}$ tersedia sebesar $56,26 \%$, serapan $\mathrm{P}$ tanaman sebesar $65 \%, \mathrm{pH}$ tanah sebesar $6,06 \%$ dan $\mathrm{C}$ organik tanah sebesar $62,68 \%$.

2. Pemberian Mikoriza Vesicular Arbuskular pada dosis $20 \mathrm{~g}$ mempunyai efektifitas yang lebih baik dalam meningkatkan $\mathrm{P}$ tersedia tanah pada tanaman kedelai. Hal ini dikarenakan Mikoriza Vesicular Arbuskular pada dosis $20 \mathrm{~g}$ mampu meningkatkan $56,26 \% \quad \mathrm{P}$ tersedia pada tanaman kedelai

\section{Ucapan Terima Kasih}

Pada kesempatan ini penulis ingin mengucapkan terima kasih kepada semua pihak yang telah membantu dengan caranya masing-masing dalam melengkapi tulisan ini.

\section{DAFTAR PUSTAKA}

Anonimus. tt. Pupuk Hayati Mikoriza Untuk Pertumbuhan dan Adaptasi Tanaman di Lahan Marginal. htt:/www. Kamus ilmiah. com/ teknologi/ pupuk hayati-mikorizauntuk pertumbuhan dan adaptasi tanaman di lahan marginal.

Atman. 2006. Pengelolaan Tanaman Kedelai di Lahan Kering Msasam.J.Ilmiah Tambua.

Beethlenfalvay, G.J., abd R. G. Linderman, (ed). 1992. Mycorrhizae in Sustainable Agric ultur. American Sociaty of Agronomi, Inc. Madison, Wisconsin, USA.

Dinas Pertanian Kabupaten Ende. 2007. Luas Panen, Produktivitas dan Produksi Tanaman Kedelai.

Erniyani. K. 2010. Uji Efektivitas Strain Bradyrhizobium japonicum yang Diisolasi dari Beberapa Lokasi di Ende Terhadap Pembentukan Nodul dan Penambatan Nitrogen pada Tanaman Kedelai (Glucyne max l).

Imas, T., Ratna, S.H., agustin, W.G., Yadi, S. 1989. Mikrobiologi Tanah II. Bogor: Departemen Pendidikan dan Kebudayaan Direktorat Jenderal Pendidikan Tinggi Pusat Antar Universitas Bioteknologi Institut Pertanian Bogor.

Gomez, K.A.,Gomez,A.A 2007. Prosedur statistic untuk penelitian pertanian. 
Julianus: Pengaruh dosis pupuk mikoriza vesikular arbuskular terhadap sifat kimia tanah pada tanaman kedelai (Glycine max (L) Merr).

Edisi ke 2.Jakarta : Universitas Indonesia.

Hidajat, O. O. 1985. Morfologi Tanaman kedelai. Dalam: Somaatmadja,S, Ismunadji, M, Sumarno, Syam, M, manurung, S. O., Yuswadi Editor. Kedelai Bogor: Pusat penelitian dan Pengembangan Tanaman Pangan.

Marwoto, Suharsono. 2008. Strategi dan Komponen Teknologi Pengendalian Ulat GrayakSpodoftera Litura Fabricius pada Tanaman Kedelai. J. Litbang Pertanian.

Niswati, A., S. G. Nugroho, M. Utomo, dan Suryadi. 1996. Pemanfaatan vesikula arbuskula untuk mengatasi pertumbuhan tanaman jagung akibat cekaman kekeringan. J. Tanah Tropika. $3: 26-31$

Nursyamsi, D., Gusmaini, dan A. Wijaya. 2003. Serapan $P$ tanah Inceptisols, Ultisols, Oxisols, dan Andisols serta kebutuhan pupuk $\mathrm{P}$ untuk beberapa tanaman pangan. Agric. Jurnal Ilmu Pertanian, Vol. 16 No. 2:103-114.

Rahayu, Y. S. dan Santoso, 1995. Pengaruh mikoriza vesikular arbuskular terhadap penyerapan dan distribusi unsur mangan (Mn) pada Capsicum annum L. danSolanum Tuberosum L. yang ditumbuhkan pada tanah Ultisol. Berkala penelitian PS-UGM, 9 (1c): 99-109.

Sastrahidayat, I. R., K. Wahidah dan Syehfani. 1999. Pengaruh Mikoriza Vesikula Arbuskula terhadap Peningkatan enzim fosfatase, beberapa asam organik dan pertumbuhan kapas (Gossypium hirsutum L.) pada vertisol dan alfisol. Agrivita. 21 (1): 10-19.

Setiadi, Y. 1989. Pemanfaatan Mikro Organisme Dalam Kehutanan. Bogor:Departemen Pendidikan dan Kebudayaan Direktorat Jenderal
Pendidikan Tinggi. Pusat Antar Universitas Bioteknologi Institut Pertanian Bogor.

Siswin, R M., Mulyati, Lolita, E.S, tt. Peranan Kascing dan Inokulasi Jamur Mikoriza terhadap Serapan Hara Tanaman Jagung. Mataram: Universitas Mataram. 16 hal.

Simanungkalit, R.D.M., Didi, A.S., Rasti, S., Diah, S., Wiwik, H. 2006. Pupuk Organikdan Pupuk Hayati. Balai Besar Litbang Sumber Daya Lahan Pertanian. Bogor: Badan Penelitian dan Pengembangan Pertanian.

Suciatmih. 1996. Bagaimana Jamur Mikoriza Vesikular-arbuskular meningkatkan ketersediaan dan Pengambilan Fosfor. Warta Biotek, tahun X, No.4. Hlm.4-7.

Suarta. I. N. 2004. Pengaruh Dosis Mikoriza dan beberapa varietas kopi robusta terhadap pertumbuhan batang bawah bibit kopi di desa Kecamatan Kintamani, Kabu Bangli.

Surnamo, R., Surnarno dan Ono Sutrisno. 1976. Laporan Tahunan Kacang-kacangan 1975. Sub Proyek Pemuliaan. Lembaga Pusat Penelitian Pertanian Bogor. Stensilan.

Talanca, A.H., Soenartiningsih, S. Rahamma, dan W. Wakman. 2001. Penggunaan Jamur Mikoriza Vesikular-Arbuskular (MVA) untuk Pengendalian Penyakit Hawar Upih Daun Jagung (Rhizoctonia solani). Risalah Penelitian Jagung dan Serealia Badan Litbang Pertanian. Vol. 5. hlm. 47-52.

Talanca, A.H., dan A.M. Adnan. 2005. Mikoriza dan Manfaatnya pada Tanaman. Prosiding Perhimpunan Entomologi dan Fitopatologi Indonesia. Hlm.311-315. 